\title{
Educational Contributions in Family and Participative Extracurricular on Students' Prosocial Behavior
}

\author{
Nur Hasanah Harahap ${ }^{1 *}$, Daharnis ${ }^{1}$, Syahniar ${ }^{1}$ \\ ${ }^{1}$ Universitas Negeri Padang \\ *Corresponding author, e-mail: hasanahamoeslim@gmail.com
}

\begin{abstract}
This research was to describe the educational contribution in family and about being active while participating extracurricular on prosocial behavior of students in SMK Negeri 6 Padang. This research applied descriptive quantitative method. The population was 903 students in $\mathrm{X}$ and XI grade at SMK Negeri 6 Padang and 278 students as the sample were selected using proportional random sampling techniques. The instruments used was questionnaire. The data were analyzed with regression statistics, simple and double regressions. The data analysis was assisted using the SPSS 20.0 program. The study showed that: (1) the average of prosocial behavior was in the high category, (2) education in family was in the high category, there were $28 \%$ contribution of education in family to prosocial behavior, (3) the activity in participating extracurricular was in the high category, there were $16.2 \%$ contributions of activeness to participate in participative extracurricular on students' prosocial behavior, (4) there were $31.5 \%$ contributions of both educational contribution in family and participative extracurricular on students' prosocial behavior.
\end{abstract}

Keywords: Prosocial Behavior, Family Education, Participative Extracurricular

How to Cite: Harahap, N.H., Daharnis, D., Syahniar, S. (2020). Educational Contributions in Family and Participative Extracurricular on Students' Prosocial Behavior. International Journal of Research in Counseling and Education. 4(1), 40-45

This is an open access article distributed under the Creative Commons 4.0 Attribution License, which permits unrestricted use, distribution, and reproduction in any medium, provided the original work is properly cited. $@ 2020$ by author and UniversitasNegeri Padang.

\section{Introduction}

Prosocial behavior is defined as the act of helping others voluntarily for the welfare of that person (Eisenberg, Cumberland, \& Spinrad, 1998; Randall \& Carlo, 2014; ), who gives a sense of satisfaction to the helper for helping others (Baron \& Byrne, 2005; Desmita, 2009; Bashori, 2018). Prosocial behavior can be demonstrated by making charitable donations, helping people in an accident, giving a seat to parents on a bus, lending goods to friends (Maner \& Gailliot, 2006). Prosocial behavior is not only done when a disaster occurs, where all people flocked to provide assistance and shown an empathy for victims, prosocial behavior is also shown in small things in daily life and becomes human responsibility as social beings (Maghfiroh \& Suwanda, 2017).

As a part of the society, adolescent has a responsibility and take a part in their social environment. Adolescents are full of feelings that are uncertain, anxious, confused, also raging hopes, challenges, fun, and misery (Sihotang, Yusuf, \& Daharnis, 2013), but they are expected to make an improvement in the society and having a good personality (Santrock, 2007). Prosocial behavior can be done by adolescents in the school environment by voluntarily lending their stationery to friends in need, helping friends to review lessons who do not understand, visiting friends who are sick, listening to the friends complaint, and avoiding behavior that violates the rights and welfare (Maghfiroh \& Suwanda, 2017).

Prosocial behavior as a religious and moral rules (Sears, Freedman, \& Peplau, 2005) have been decreased in adolescents (Farida, 2017). Modernization causes humans to competition to be the best, by encouraging them to think only about themselves and making them to e selfish human beings. The hedonic lifestyle, makes them just think about their own pleasure without thinking about others situation. In the school environment, those behavior are done by breaking the school's regulation, not doing homework, talking rude to each other, unable to cooperate and bothering friends (Putra, Gistituati, \& Syahniar, 2015; Rahayu, Firman, \& Yarmis Syukur, 2014; Aida, 2018), even more there is a tendency for students to gather in a group with the same religion (Andris Noya, 2019). If this behaviors are continusing to do, it will lead the 
worst antisocial behavior, such as aggressiveness, persecution, violence, selfishness, destruction, arbitrary action and so on (Zakaria, 2016).

Prosocial behavior is important to be improved for adolescents in their social interactions so that they are sensitive to their emotional and affective conditions. Adolescent who are far from social expectations will get worse adjustments and social interactions and are rejected in the social environment (Afrianti \& Anggraeni, 2016; Marlina, 2014). Prosocial behavior has a positive influence on others, increases social adjustment and creates harmony in society (Lestari, 2016).

Many factors affect prosocial behavior in a person, one of them is parenting (Desmita, 2009). Education in the family affects the life of society, nation, and state, so this is important to give to the students, if family education is good, then the life of the community is good too (Wahidin, 2017). The role of parents in nurturing, guiding, educating, supervising, and paying attention as an example of the formation of prosocial behavior (Sarwono \& Meinarno, 2011). The warmth, support, and positive emotions displayed by parents while interacting with children provide opportunities for learning for children to interact with others (Pastorelli et al., 2016). The family is the first social place for children to get social and prosocial education (Hyson \& Taylor, 2011). Children tend to imitate what their parents do and these characteristics will settle on the child (Warneken \& Tomasello, 2009). Positive cooperation between father and mother in parenting will shape the child's positive behavior in others (David, Daharnis, \& Said, 2014).

Another factor that can influence the formation of prosocial behavior in a person is peers (Desmita, 2009; Dijkstra \& Gest, 2015). Teenage peers having interpersonal relationships, through good interpersonal relationships teens can develop social identities, and reduce antisocial behavior (Hughes, 2016). Interpersonal relationship skills can be improved by participating in extracurricular activities (Dazeva \& Tarmidi, 2012). Communities in extracurricular activities as coaching are different from the formation of clear identities, prosocial (Martinez, Coker, Mcmahon, Martinez, \& Coker, 2016) and moral norms (Fadhlyda, Erlamsyah, \& Daharnis, 2014). Extracurricular activities can foster students' emotional intelligence, interact with others and cooperate, children will respect others, learn to control emotions, empathize, and help one another (Mahoney, Larson, \& Eccles, 2005). Extracurricular activities in the form of groups will form bonds and a sense of belonging with fellow group members, the positive feelings that are associated show a positive relationship in the formation of prosocial behavior (Bruner et al., 2018). Involvement in extracurricular activities not only fosters high prosocial behavior but also prevents students from juvenile delinquency (Hughes, Cao, \& Kwok, 2016).

\section{Method}

The research method used a quantitative approach with a descriptive correlational type and double regression. This research was conducted at SMK Negeri 6 Padang, the population of this study was students of class X \& XI, it was about 278 students from 903 students who were selected by proportional random sampling technique. The method of data collection was a questionnaire with a Likert scale. There were 3 questionnaires for data collection, namely the scale of prosocial behavior, the scale of education in family and the scale of activeness in participating extracurricular. The validity results of this method, there were 6 failed points of prosocial behavior, 8 failed points of education in the family, and 2 failed points of participating in extracurricular activities. So, it resulted 33 points of prosocial behavior, 55 points of education in the family, and 27 points in participating extracurricular activities. And also, the result of reliability instruments are 0.862 for prosocial behavior, 0.950 for education in the family, and 0.950 for activeness in participating extracurricular activities. Therefore,this instrument can be stated as reliable category in the high coefficient of reliability. The data were analyzed by simple and double regression statistics. The data analysis was assisted using the SPSS 20.0 program.

\section{Results and Discussion}

The data in this research included variables of family education (X1), participating in extracurricular actively (X2), prosocial behavior (Y). The following was the resulted data of the research. 
Table 1. Distribution of Frequency and Percentage of Family Education (X1), Participating in Extracurricular Actively (X2), and Prosocial Behavior (Y)

\begin{tabular}{ccccccc}
\hline \multirow{2}{*}{ Category } & \multicolumn{2}{c}{ Family Education } & \multicolumn{2}{c}{$\begin{array}{c}\text { Participating in } \\
\text { Extracurricular Actively }\end{array}$} & \multicolumn{2}{c}{ Prosocial Behavior } \\
\cline { 2 - 7 } & Frequency & $\%$ & Frequency & $\%$ & Frequency & $\%$ \\
\hline Very high & 68 & 25 & 79 & 28 & 23 & 8 \\
High & 157 & 56 & 107 & 39 & 188 & 68 \\
Medium & 53 & 19 & 88 & 32 & 67 & 24 \\
Low & 0 & 0 & 4 & 1 & 0 & 0 \\
Very low & 0 & 0 & 0 & 0 & 0 & 0 \\
\hline Total & $\mathbf{2 7 8}$ & $\mathbf{1 0 0}$ & $\mathbf{2 7 8}$ & $\mathbf{1 0 0}$ & $\mathbf{2 7 8}$ & $\mathbf{1 0 0}$ \\
\hline
\end{tabular}

The Table 1 above showed that some students have very high education in family at $25 \%$, a high category at $56 \%$, a medium category at $19 \%$, and there are no students in the low and very low categories. On average, family education of students was in the high category. Then for the active variables of participating in extracurricular activities, it can be seen that students were in the very high category at $28 \%$, the high category at $39 \%$, the medium category at $32 \%$, the low category $1 \%$, and there are no students in the very low category. On average, the activeness in participating extracurricular was in the high category. Furthermore, the prosocial behavior variable showed that students have very high prosocial behavior that was equal to $8 \%$, in the high category by $68 \%$, in the moderate category by $24 \%$, and there are no students in the low and very low categories. On average, students' prosocial behavior was in the high category.

Table 2. Analysis Result of Family Educational Contribution (X1) to Prosocial Behavior (Y)

\begin{tabular}{cccc}
\hline Model & $\mathbf{R}$ & $\boldsymbol{R}$ Square & Sig. \\
\hline $\mathrm{X} 1-\mathrm{Y}$ & 0,529 & 0,280 & 0,000 \\
\hline
\end{tabular}

In Table 2, it can be seen that the value of $\mathrm{R} 0.529$ which showed the coefficient of education in family of students' prosocial behavior. Then, the value of R Square (r2) of 0.280 means contributes education in family to prosocial behavior by $28 \%$, while $72 \%$ was influenced by other factors.

The warmth, support, and positive emotions displayed by parents when interacting with children provide opportunities for learning for children to interact with others. Rules that are applied at home, discipline, guidance, and direction on the child's behavior, will be attached to the child's personality and form prosocial behavior (Pastorelli et al., 2016). Conversely, in families that show too much anger, bad parental relationships, parents often insult children when angry, irregular emotional control forms bad social functions. (Havighurst, Wilson, Harley, Prior, \& Kehoe, 2010). When children begin to grow up they are more aware, willing to accept and feel the behavior of parents in exemplifying prosocial behavior (Pastorelli et al., 2016). The students who get a good family education can influence, share, help and cooperate their prosocial behavior each other, and be honest in their daily interactions, both within the family and the community.

Table 3. Analysis Result in Participating Extracurricular Actively Contribution (X2) to Prosocial Behavior $(\mathrm{Y})$

\begin{tabular}{cccc}
\hline Model & $\mathbf{R}$ & $\boldsymbol{R}$ Square & Sig. \\
\hline $\mathrm{X} 2-\mathrm{Y}$ & 0,402 & 0,162 & 0,000 \\
\hline
\end{tabular}

In Table 3 it can be seen that the R-value of 0.402 which showed the coefficient of participating in extracurricular activities on students' prosocial behavior. Then, the value of R Square (r2) of 0.162 means that the activity of participating in extracurricular activities contributed to prosocial behavior by $16.2 \%$. This means that the activity of participating extracurricular activities is one of the factors that contribute to prosocial behavior.

Extracurricular activities as a component of self-development can develop students' abilities and sense of social responsibility (Narmoatmojo, 2010) and uphold social values (Isro \& Warsono, 2017). Extracurricular activities in the form of groups will form bonds and a sense of belonging with fellow group 
members, positive feelings that are associated show a positive relationship in the formation of prosocial behavior (Bruner et al., 2017). Extracurricular activities carried out with fun and packaged as interesting as possible will be more sought after by students (Aida, 2018).

Extracurricular activities accustom students to interact and cooperate with others, with habituation that students will more easily carry out social responsibility in the community. Through extracurricular, students learn to be responsible, sharing what they have, helping group friends, and sportsmanship in activities.

Table 4. Analysis Result of the Educational Contribution in Family (X1), and Participating in Extracurricular Actively (X2) on Prosocial Behavior (Y)

\begin{tabular}{cccc}
\hline Model & $\mathbf{R}$ & $\boldsymbol{R}$ Square & Sig. \\
\hline $\mathrm{X} 2-\mathrm{Y}$ & 0,561 & 0,315 & 0,000 \\
\hline
\end{tabular}

In Table 4, it can be seen that the R-value of 0.561 which showed the double regression coefficients between family education and the participating in extracurricular actively on students' prosocial behavior. $\mathrm{R}$ Square (R2) value of 0.315 means that education in family and active participation in extracurricular activities contribute to prosocial behavior by $31.5 \%$. While the remaining $68.5 \%$ is influenced by other factors not discussed in this study.

Based on the findings above, it can be seen that education in the family and being participative in extracurricular activities were factors that influence students' prosocial behavior. Education in family as an example of the child's first behavior in social interaction in the community, so that ultimately students' who have good family education will have good prosocial behavior in their environment. The activeness in participating extracurricular activities as well, as a forum for learning outside of school that accustoms students to interact and cooperate with others, so that prosocial behavior is embedded from the activities that are followed by students

\section{Conclusion}

Based on the results of this research, it can be concluded that on average education in family, being participative in extracurricular activities, students' prosocial behavior were in the high category. Furthermore, education in family contributed significantly to students' prosocial behavior by $28 \%$, active participation in extracurricular actively contributes significantly to students' prosocial behavior by $16.2 \%$, both of education in family and active participation in extracurricular activities contribute to prosocial behavior of students of SMK Negeri 6 Padang by 31.5\%. This means that the level of prosocial behavior of students was not only influenced by one variable (family education or parcipating in extracurricular actively), but was influenced by both education in family and being participative in extracurricular activities. In other words, the higher education was applied in a family and the more the students in an extracurricular activities, the better prosocial behavior is formed. This means that the educational variables of family and participating in extracurricular actively will be more effective if combining as a predictor to improve student prosocial behavior rather than just one variable. The results of this research must also be the concern of the school and parents/guardians of students.

\section{References}

Afrianti, N., \& Anggraeni, D. (2016). Perilaku prososial remaja dalam perspektif bimbingan konseling islami. Jurnal Pendidikan Islam, 5(1), 77-90.

Aida, W. N. (2018). The effect of school culture and scout extracurricular to the prosocial behavior of students in elementary school. Advances in Social Science, Education and Humanities Research, 222(SoSHEC), 247-252.

Andris Noya. (2019). Hubungan kecerdasan emosi dan perilaku prososial siswa di SMA Negeri 9 Halmahera Selatan. Jurnal Penelitian Dan Pengembangan Pendidikan Dan Pengembangan Pendidikan, 2(1), $28-34$.

Bashori, K. (2018). Menyemai perilaku prososial di sekolah. Sukma: Jurnal Pendidikan, 1(1), 57-92. https://doi.org/10.32533/01103(2017)

Bruner, M. W., Boardley, I. D., Benson, A. J., Wilson, K. S., Root, Z., Turnnidge, J., ... Côté, J. (2017). 
Disentangling the relations between social identity and prosocial and antisocial behavior in competitive youth sport. Journal of Youth and Adolescence, 475), 1113-1127. https://doi.org/10.1007/s10964-0170769-2

Bruner, M. W., Boardley, I. D., Benson, A. J., Wilson, K. S., Root, Z., Turnnidge, J., ... Côté, J. (2018). Disentangling the relations between social identity and prosocial and antisocial behavior in competitive youth sport. Journal of Youth and Adolescence, 475), 1113-1127.

David, M., Daharnis, D., \& Said, A. (2014). Persepsi anak terhadap peran ayah dalam keluarga dan implikasinya terhadap pelayanan bimbingan dan konseling. Jurnal Konseling Dan Pendidikan, 2(1), 25-29.

Dazeva, V., \& Tarmidi. (2012). Perbedaan kecerdasan emosional siswa ditinjau dari jenis kegiatan ekstrakurikuler. Psikologia, 72), 81-92.

Desmita. (2009). Psikologi perkembangan peserta didik. Bandung: Remaja Rosdakarya.

Eisenberg, N., Cumberland, A., \& Spinrad, T. L. (1998). Parental socialization of emotion. Psychological Inquiry (Vol. 9).

Fadhlyda, R., Erlamsyah, \& Daharnis, D. (2014). Pembinaan kegiatan ekstrakurikuler di SMPN kota Sawahlunto. Jurnal IImiah Konseling, 3(3), 100-105.

Farida, H. (2017). Perilaku prososial siswa ditinjau dari androgyny role. Jurnal LP3M, 3(2), 113-126.

Havighurst, S. S., Wilson, K. R., Harley, A. E., Prior, M. R., \& Kehoe, C. (2010). Tuning in to kids : improving emotion socialization practices in parents of preschool children - findings from a community trial. Journal of Child Psychology and Psychiatry, 12(51), 1342-1350. https://doi.org/10.1111/j.14697610.2010.02303.x

Hughes, J. N. (2016). Indirect effects of extracurricular participation on academic adjustment via perceived friend's prosocial norms. Journal of Youth and Adolescence, 45(11), 2260-2277. https://doi.org/10.1007/s10964-016-0508-0

Hughes, J. N., Cao, Q., \& Kwok, O. (2016). Indirect effects of extracurricular participation on academic adjustment via perceived friends' prosocial norms. Journal of Youth and Adolescence, 45(11), 2260 2277.

Hyson, M., \& Taylor, J. L. (2011). Caring about Caring : What Adults Can Do to Promote. Young Children, 66(4), 74-83.

Isro, S. D., \& Warsono. (2017). Ekstrakurikuler palang merah remaja dalam menumbuhkan kepedulian sosial di SMP Negeri 2 Jombang. Kajian Moral Dan Kewarganegaraan, 5(2), 288-302.

Lestari, R. (2016). Transmisi nilai prososial pada remaja jawa. Jurnal Indigenous, 1(2), 33-44.

Maghfiroh, R. L., \& Suwanda, I. M. (2017). Hubungan antara kecerdasan emosional dengan perilaku prososial siswa di SMP Negeri 2 Sidoarjo. Kajian Moral Dan Kewarganegaraan, 5(1), 196-210.

Mahoney, J. L., Larson, R. W., \& Eccles, J. S. (2005). Organized activities as contexts of development: extracurricular activities, after school and community programs. (J. L. Mahoney, Ed.). New Jersey: Psychology Press.

Maner, J. K., \& Gailliot, M. T. (2006). Altruism and egoism : Prosocial motivations for helping depend on relationship context. European Journal of Social Psychology, (August 2005), 1-12. https://doi.org/10.1002/ejsp.364

Marlina. (2014). Keterampilan sosial anak berkesulitan belajar di sekolah dasar inklusif. Jurnal Penelitian Pendidikan, 5(1), 9-21.

Martinez, A., Coker, C., Mcmahon, S. D., Martinez, A., \& Coker, C. (2016). Involvement in extracurricular activities: identifying differences in perceptions of school climate involvement in extracurricular activities : identifying differences in perceptions of school climate. The Educational and Developmental Psychologist, 33(1), 70-84. https://doi.org/10.1017/edp.2016.7 
Narmoatmojo, W. (2010). Ekstrakurikuler di sekolah: dasar kebijakan dan aktualisasinya. Artikel. Retrieved from www.academia.edu

Pastorelli, C., Lansford, J. E., Paula, B., Kanacri, L., Patrick, S., Giunta, L. Di, ... Deater-deckard, K. (2016). Positive parenting and children's prosocial behavior in eight countries. Journal of Child Psychology and PSychiatry, 757), 824-834. https://doi.org/10.1111/jcpp.12477

Putra, H. P., Gistituati, N., \& Syahniar. (2015). Peningkatan perilaku prososial siswa di sekolah melalui layanan bimbingan dan konseling dengan teknik modeling. Jurnal Konseling Dan Pendidikan, 3(2), 31-39.

Santrock, J. . (2007). Remaja, jilid 2, edisi Kesebelas. (B. Widyasinta \& N. I. Sallama, Eds.) (11th ed.). Jakarta: Erlangga.

Sarwono, S. W., \& Meinarno, E. A. (2011). Psikologi sosial. (R. Oktafiani, Ed.). Jakarta: Salemba Humanika.

Sears, D. O., Freedman, J. L., \& Peplau, L. A. (2005). Psikologi sosial. In M. Adryanto (Ed.), Jilid 2(Kelima, pp. 4774). Jakarta: Erlangga.

Sihotang, N., Yusuf, A. M., \& Daharnis, D. (2013). Pengaruh layanan bimbingan kelompok terhadap pencapaian tugas perkembangan remaja awal dalam aspek kemandirian emosional ( studi eksperimen di SMP Frater Padang ). Jurnal Ilmiah Konseling, 2(4), 172-185.

Wahidin, U. (2017). Peran strategis keluarga dalam pendidikan anak. Edukasi Islami: Jurnal Pendidikan Islam, 1(2), 1-9.

Warneken, F., \& Tomasello, M. (2009). The roots of human altruism. In Journal of Psychology (Vol. 100, pp. 455-471). https://doi.org/10.1348/000712608X379061

Zakaria, A. F. (2016). Studi tentang upaya guru IPS dalam mengembangkan perilaku prososial dan mengurangi perilaku bullying siswa di SMP. Jurnal Pendidikan IImu Sosial, 25(1), 117-124. 